\title{
Diffuse Large B-Cell Lymphoma Transformed from \\ Mucosa-Associated Lymphoid Tissue Lymphoma Arising in a Female Urethra Treated with Rituximab for the First Time
}

\author{
A. Al Zahrani ${ }^{a} \quad$ M. Abdelsalam ${ }^{a} \quad$ A. Al Fiaar ${ }^{b} \quad$ N. Ibrahim ${ }^{a}$ \\ A. Al-Elawi ${ }^{\mathrm{C}}$ B. Muhammad ${ }^{\mathrm{a}}$ \\ ${ }^{a}$ Oncology Department, ${ }^{b}$ Histopathology Department, and ' Urology \\ Department, Riyadh Military Hospital, Riyadh, Kingdom of Saudi Arabia
}

\section{Key Words}

Urethra $\cdot \mathrm{NHL} \cdot$ Chemotherapy $\cdot$ Malignant lymphoma $\cdot$ Female urethra $\cdot$ CHOP-R chemotherapy

\begin{abstract}
A 30-year-old female patient presented to the gynecology clinic with a small (painless) swelling at the urethral orifice. She underwent surgical excision of the lesion. Pathological examination revealed non-Hodgkin's lymphoma of diffuse large B-cell type and mucosaassociated lymphoid tissue type, stage IE. The patient refused radiotherapy. Accordingly, we started CHOP-R chemotherapy. She received a total of 6 cycles of CHOP and 8 cycles of rituximab. Patient follow-up was done 3 months later through CT scan and cytoscopy confirming the complete remission. The patient has been disease-free for 4 years. We reviewed 26 cases of this rare entity reported previously.
\end{abstract}

\section{Introduction}

Lymphoma constitutes approximately 7\% of all urogenital neoplasm [1]. The most frequent finding is of bladder involvement secondary to nodal disease [2]. Although cases of urethral lymphoma have been reported, the majority involve tumors arising in mucosa-associated lymphoid tissue (MALT) $[3,4]$. Primary tumors arising from the urethra remain case reportable. Of the cases of primary urethral lymphoma that have 
been described, 19 cases have been reported in female patients and 7 cases in men, 1 of which was associated with HIV infection [1, 5-7]. Limited clinical experience has resulted in uncertainty concerning the most appropriate form of therapy for this malignancy.

\section{Case}

In February 2007, a 30-year-old woman presented to the gynecology clinic with a small painless mass at the urethral orifice. She underwent surgical excision of the lesion and histopathology revealed a mixture of acute and chronic inflammation consistent with urethral carbuncle. Two months later she presented with a hyperemic small swelling at the site of the excision. She underwent re-excision; and a mass from the urethral mucosa was biopsied. Pathologic examination of the specimen revealed a diffuse monotonous proliferation of malignant lymphoid cells of mostly large cell size; some of which are medium size and have a monocytoid appearance. The urethral mucosa above the infiltrate is focally infiltrated by malignant lymphoid cells (fig. 1, fig. 2). The deep component of the tumor infiltrates the glandular epithelium of the urethra (lymphoepithelial lesion); a feature strongly suggestive of MALT lymphoma ( $\underline{\text { fig. } 3}$ ). Immunohistochemistry for cytokeratin highlights these lesions (fig. 4, fig. 5). Immunocytochemistry studies demonstrated that the tumor cells have a strong positive reaction to CD45 (leukocytic common antigen, LCA) and CD20 (fig. 6 ).

For staging workup she underwent chest, abdomen and pelvis CT which revealed no mediastinal lymphadenopathy, no lung focal lesion, a 3-mm cystic focus on the right lobe of the liver, normal spleen, pancreas and kidney, and no abdominal or pelvic lymphadenopathy. There is a slight apparent localized thickening of the bladder neck. MRI of the hepatic lesion revealed a simple benign cyst. Blood workup including LDH, ESR, $\beta_{2}$ microglobulin, HIV, hepatitis and STD profile was done and all were normal. Bone marrow examination was negative. Upper gastrointestinal endoscopy did not reveal any MALT-associated lesions. Therefore, the final diagnosis was non-Hodgkin's lymphoma of female urethra, diffuse large B-cell, possibly transformed from MALT lymphoma, stage IE according to Cotswolds modification of the Ann Arbor staging system.

The patient was offered localized radiotherapy. She refused this modality after being counseled about the possible side effects including the high possibility of infertility. Accordingly, we offered her chemotherapy (R-CHOP regimen including, rituximab, cyclophosphamide, doxorubicin, vincristine, and prednisolone). The patient underwent staging reassessment with CT scan and cytoscopy after 4 chemotherapy cycles. Multiple biopsies revealed a complete remission. A total of 6 cycles of CHOP and 8 cycles of rituximab were completed. Patient follow-up was done 3 months later with CT scan and cytoscopy confirming the complete remission. The patient has been free of disease for 4 years.

\section{Discussion}

Caruncles are the most common lesions of the female urethra; they are inflammatory nodules that arise at the urethral meatus in postmenopausal women [8]. Urethral caruncles usually arise from the posterior lip of the urethral meatus. The lesion is considered to be neither neoplastic nor preneoplastic, but probably results from local trauma or inflammation. However, carcinoma (1.6\%) and Bowen's disease (0.8\%) are extremely rare and have been noted in $2.4 \%$ of patients with a clinical diagnosis of urethral caruncle. Macroscopically, a caruncle is a nodular or pedunculated erythematous lesion that may bleed easily.

Lymphoma of the female urethra, on the other hand, is an exceedingly rare condition. The literature describes only 27 cases (19 of them were female and 8 were male; table 1). All were non-Hodgkin's lymphoma [9-13]. The age distribution ranged from 31 to 90 years with a mean of 67 years. The most common reported complaints 
were polyp, dysuria, urethral mass, irregular vaginal bleeding, gross hematuria, pain, urinary retention, carbuncle, and genital itching [13-17].

Four cases have been reported as having a painless mass at the urethral meatus resembling a caruncle as in our own case $[9,10]$. Two cases were treated with radiotherapy, one case was treated with excision, and the last was treated palliatively. Our case is the first urethral lymphoma case treated with chemotherapy (CHOP-R). Another male urethral case was treated with CHOP without rituximab. In that described case of primary lymphoma of a male urethra, the patient remained alive and in complete remission 2 years after surgical removal and 6 courses of CHOP chemotherapy. It has been reported that prognosis for short-term local control of the urethral tumor with chemotherapy is excellent; recent cases show a short-term control rate of $100 \%$ [18].

\section{Conclusion}

There is no universally accepted treatment scheme for these tumors. Although, several authors have reported reasonable success using excision, radiotherapy, chemotherapy, or combinations. Although the number of cases reported was very small and the follow-up period was short in all cases, local therapy including excision or external beam radiation with/without chemotherapy showed a good outcome in patients with local or locally invasive tumor. However, patients with disseminated disease showed a poor prognosis regardless of the kind of initial treatment. Accordingly, in patients with unfavorable histology or disseminated disease, early intensive chemotherapy is recommended. Use of the chemotherapy regimen CHOP-R seems to be a reasonable treatment option. For patients without bulky disease, 6-8 cycles of CHOP-R without radiotherapy have been shown to be an equally effective alternative as reported in our case [19]. Therefore, we recommend that any carunclelike lesion should be evaluated with a suspicion of a malignant tumor unless proved otherwise. 
Table 1. Summary of reported cases of primary urethral lymphoma

\begin{tabular}{|c|c|c|c|c|c|c|c|c|c|}
\hline No. & First author & Year & $\begin{array}{l}\text { Age } \\
\text { years }\end{array}$ & Sex & Chief complaint & Localization & Treatment & Outcome & $\begin{array}{l}\text { Observation } \\
\text { period }\end{array}$ \\
\hline $1^{*}$ & Grabstald [16] & 1966 & Unknown & $\mathrm{F}$ & Unknown & Unknown & Radiation & NED & 9 months \\
\hline $2^{*}$ & Nabholtz [10] & 1989 & 51 & $\mathrm{~F}$ & Urethral polyp & Localized urethral & Chemo + exci & NED & 120 months \\
\hline $3^{*}$ & Pak [11] & 1980 & 83 & $\mathrm{~F}$ & Dysuria & Localized urethral & None & Dead & Unknown \\
\hline $4^{*}$ & Simpson [12] & 1990 & 76 & $\mathrm{~F}$ & Urethral mass & Localized urethral & Excision & NED & 24 months \\
\hline $5^{*}$ & Vapnek [15] & 1992 & 31 & $\mathrm{~F}$ & Irregular vaginal bleeding & Localized urethral & Chemo + radi & NED & 9 months \\
\hline $6^{*}$ & Kakizaki [20] & 1994 & 63 & $\mathrm{M}$ & Urethral mass & Localized urethral & Chemo + exci & NED & 36 months \\
\hline $7^{*}$ & Ohsawa [21] & 1994 & 78 & $\mathrm{~F}$ & Dysuria, polyuria & Localized urethral & Chemotherapy & Unknown & Unknown \\
\hline $8^{*}$ & Khatib [2] & 1993 & 65 & $\mathrm{~F}$ & Irregular vaginal bleeding & Localized urethral & Excision & NED & 24 months \\
\hline $9^{*}$ & Atalay [19] & 1998 & 76 & $\mathrm{~F}$ & $\begin{array}{l}\text { Pain on urination, urinary tract } \\
\text { tumor }\end{array}$ & Localized urethral & None & Dead & Unknown \\
\hline 10 & Kurtman [22] & 2001 & 32 & $\mathrm{M}$ & Urinary retention & Localized urethral & Radiation & NED & 15 months \\
\hline 11 & Masuda [3] & 2002 & 56 & $\mathrm{M}$ & Gross hematuria & Localized urethral & Radiation & NED & 21 months \\
\hline 12 & Inuzuka [23] & 2003 & 69 & $\mathrm{~F}$ & Dysuria, urinary tract tumors & Localized urethral & Exci + chemo & NED & 6 months \\
\hline 13 & Ryu [24] & 2003 & 25 & M & Dysuria, tumor palpable lump & Localized urethral & Chemotherapy & NED & 67 months \\
\hline 14 & Chuang [25] & 2005 & 50 & $\mathrm{~F}$ & Caruncle & Localized urethral & Radiation & NED & $\begin{array}{l}14.5 \\
\text { months }\end{array}$ \\
\hline & Richter [18] & 2007 & 48 & $\mathrm{M}$ & Dysuria, meat hematuria eye & Localized urethral & Exci + chemo & NED & 3 months \\
\hline $16^{*}$ & Melicow [9] & 1972 & 76 & $\mathrm{~F}$ & Caruncle, hematuria & Local infiltration & TUR + radi & NED & 12 months \\
\hline $17^{*}$ & Touhami [13] & 1987 & 63 & $\mathrm{~F}$ & Genital itching, dysuria & Local infiltration & Chemotherapy & NED & 48 months \\
\hline $18^{*}$ & Selch [14] & 1993 & 75 & $\mathrm{~F}$ & Irregular vaginal bleeding & Local infiltration & Radiation & NED & 42 months \\
\hline 19* & Shimizu [26] & 1997 & 82 & $\mathrm{~F}$ & Dysuria & Local infiltration & Chemo + radi & Dead & 7 months \\
\hline $20^{*}$ & Watson [27] & 1949 & 62 & $\mathrm{~F}$ & Caruncle, spotting & Disseminated & Excision & Dead & 5 months \\
\hline $21^{*}$ & Allen [28] & 1978 & 53 & $\mathrm{~F}$ & Caruncle & Disseminated & Palliative & Dead & 2 months \\
\hline $22^{*}$ & Chaitin [29] & 1993 & 77 & $\mathrm{~F}$ & Genital mass, hematuria & Disseminated & Chemotherapy & NED & 9 months \\
\hline $23^{*}$ & Lopez [6] & 1993 & 57 & $\mathrm{M}$ & Dysuria, hematuria & Disseminated & Chemotherapy & Dead & 3 months \\
\hline $24^{*}$ & Rajan [30] & 1995 & 57 & $\mathrm{M}$ & Urinary retention, hematuria & Disseminated & Chemotherapy & NED & 6 months \\
\hline 25 & Dell'Atti [31] & 2005 & 69 & $\mathrm{~F}$ & $\begin{array}{l}\text { Dysuria, from thermal weight } \\
\text { loss }\end{array}$ & $\begin{array}{l}\text { Progressive } \\
\text { systemic }\end{array}$ & Exci + chemo & Unknown & Unknown \\
\hline 26 & Muraoka [32] & 2009 & 90 & $\mathrm{~F}$ & Dysuria & Localized urethral & Exci + radi & NED & 14 months \\
\hline 27 & Al Zahrani & 2011 & 30 & $\mathrm{~F}$ & Caruncle & & Chemotherapy & NED & \\
\hline
\end{tabular}

Exci $=$ Excision; chemo = chemotherapy; TUR = transurethral resection; radi = radiation; NED = no evidence of disease. ${ }^{*}$ Another hospital death. 


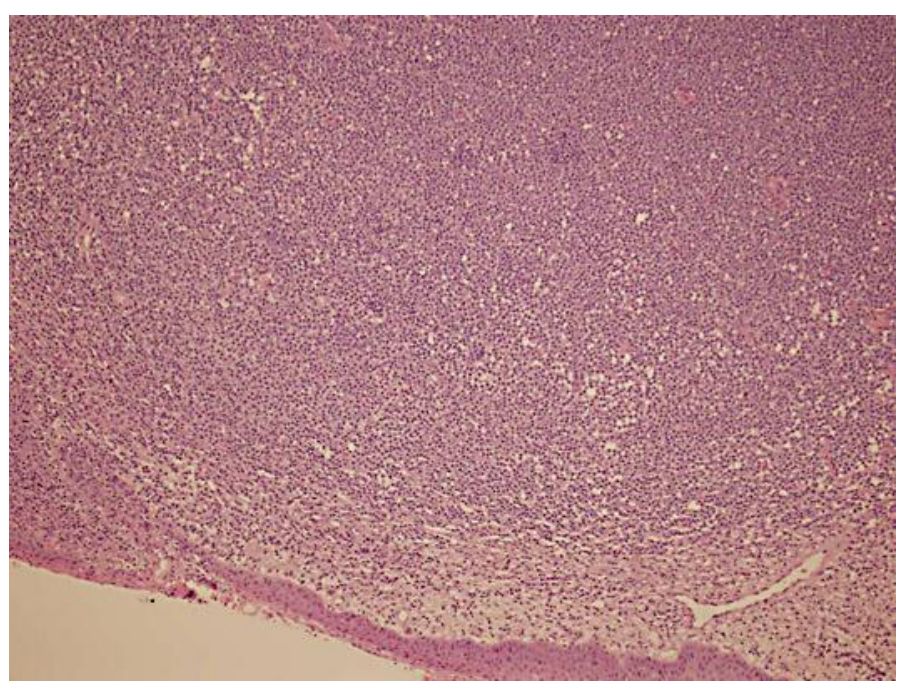

Fig. 1. Diffuse monotonous proliferation of malignant lymphoid cells, the urethral mucosa above the infiltrate is focal (hematoxylin and eosin, $\times 100$ ).

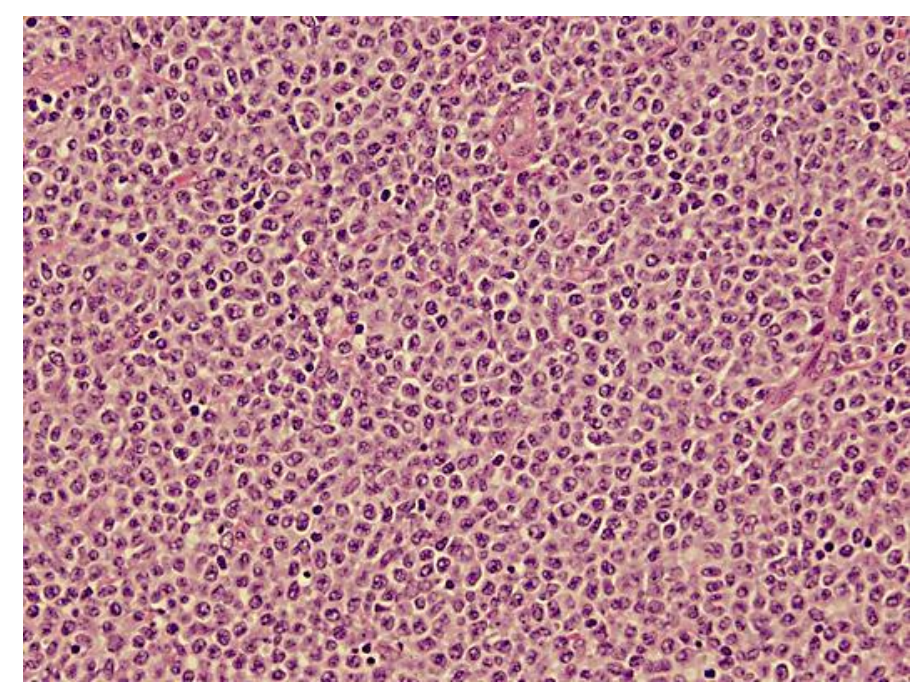

Fig. 2. Diffuse proliferation of malignant ltmphoid cells (hematoxylin and eosin, $\times 400$ ). 


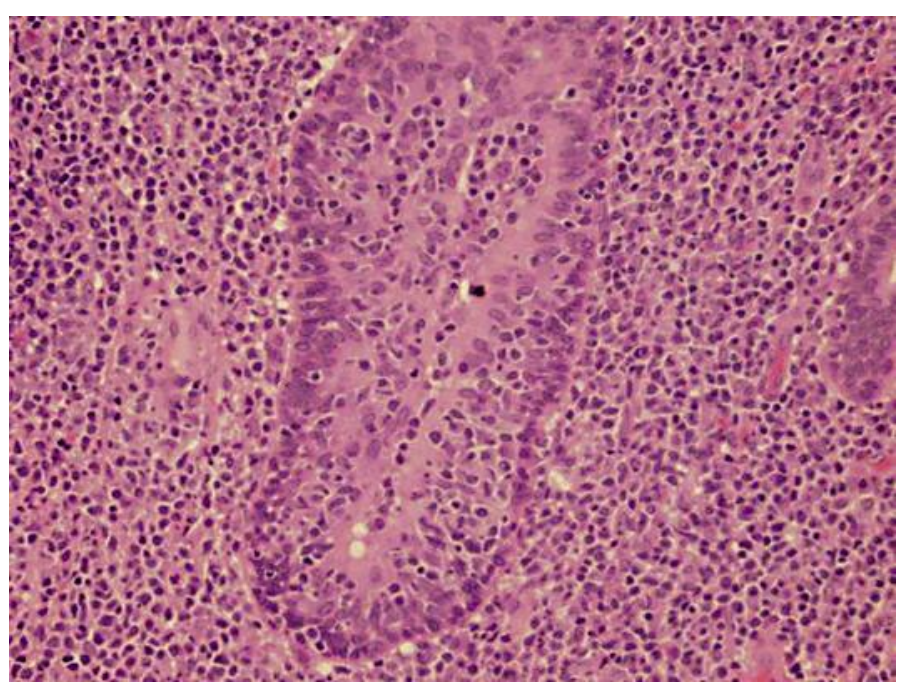

Fig. 3. Glandular epithelium of the urethra (lymphoepithelial lesion), a feature strongly suggestive of MALT lymphoma (hematoxylin and eosin, $\times 200$ ).

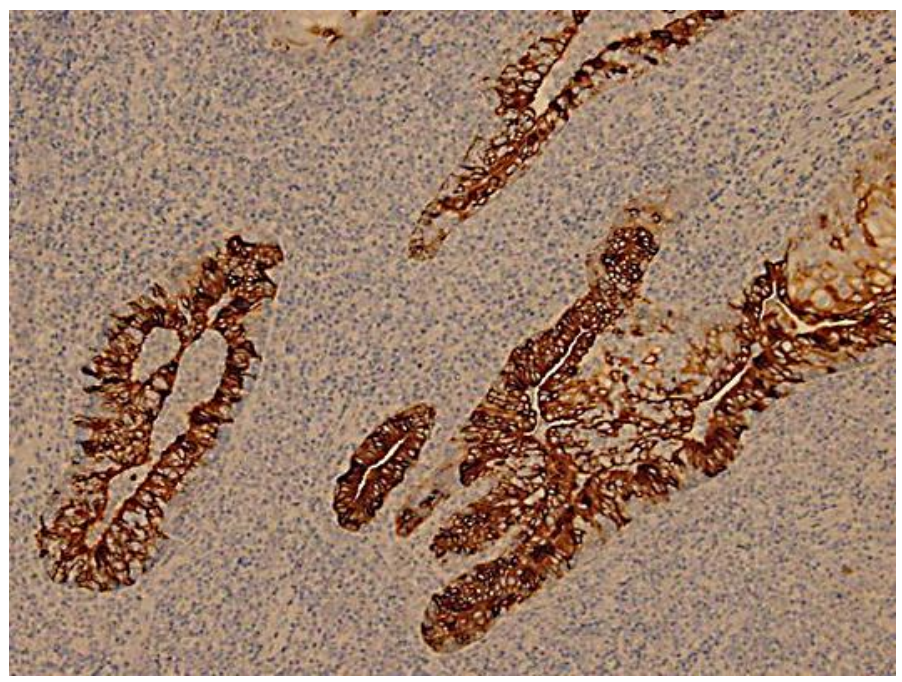

Fig. 4. Image highlights lymphoepithelial lesions; immunohistochemistry stain with cytokeratin (Dako; $\times 200)$. 


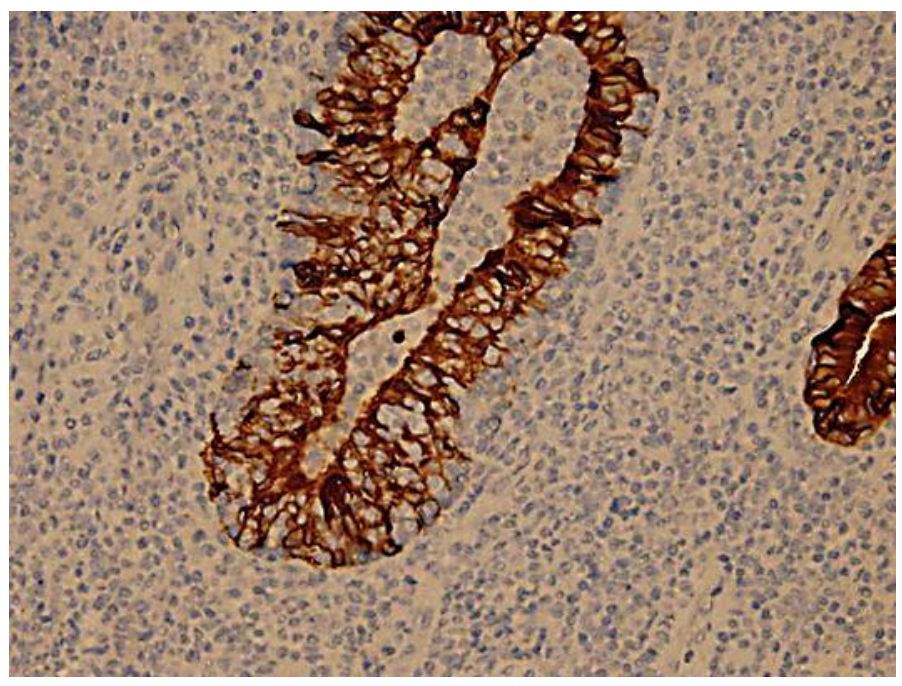

Fig. 5. Image highlights lymphoepithelial lesion; immunohistochemistry stain with cytokeratin (Dako; ×400).

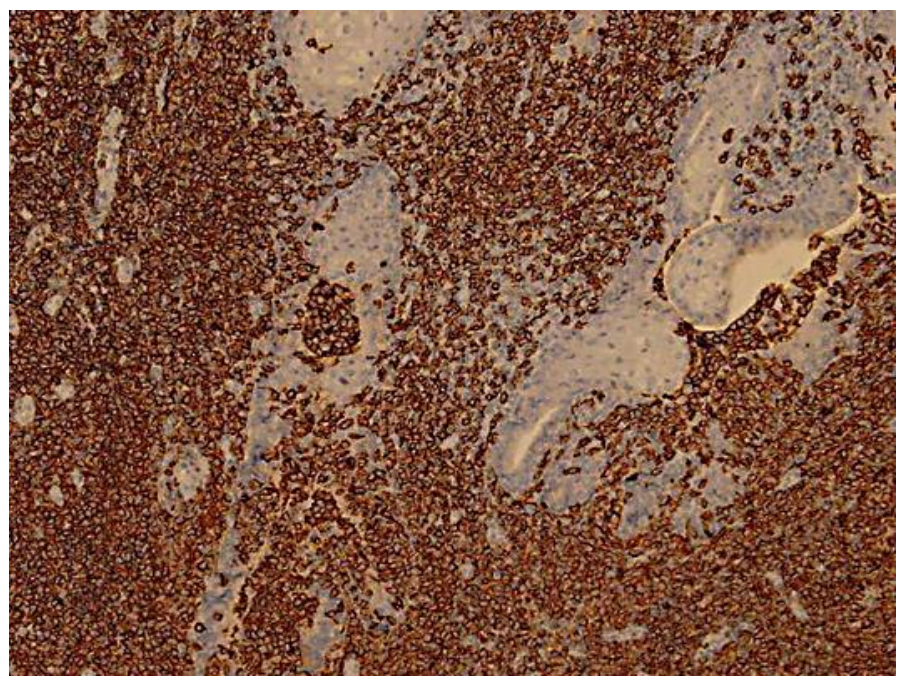

Fig. 6. Image highlights lymphoid cells with positive reaction to CD20 (Dako; ×200).

\section{References}

1 Hatcher PA, Wilson DD: Primary lymphoma of the male urethra. Urology 1997;49:142-144.

2 Khatib RA, Khalil AM, Tawil AN, et al: Non-Hodgkin's lymphoma presenting as a urethral caruncle. Gynecol Oncol 1993;50:389-393.

-3 Masuda A, Tsujii T, Kojima M, et al: Primary mucosa-associated lymphoid tissue (MALT) lymphoma arising from the male urethra. A case report and review of the literature. Pathol Res Pract 2002;198:571-575.

4 Isaacson P, Wright DH, Jones DB: Malignant lymphoma of true histiocytic (monocyte/macrophage) origin. Cancer 1983;51:80-91. 
5 Hofmockel G, Dammrich J, Manzanilla Garcia H, et al: Primary non-Hodgkin's lymphoma of the male urethra. A case report and review of the literature. Urol Int 1995;55:177-180.

-6 Lopez AE, Latiff GA, Ciancio G, Antun R: Lymphoma of urethra in patient with acquired immune deficiency syndrome. Urology 1993;42:596-598.

7 Guthman DA, Malek RS, Chapman WR, Farrow GM: Primary malignant lymphoma of the bladder. J Urol 1990;144:1367-1369.

$>8$ Weimar G, Culp DA, Loening S, Narayana A: Urogenital involvement by malignant lymphomas. J Urol 1981;125:230-231.

-9 Melicow MM, Lattes R, Pierre-Louis C: Lymphoma of the female urethra masquerading as a caruncle. J Urol 1972;108:748-749.

10 Nabholtz JM, Friedman S, Tremeaux JC, et al: Non-Hodgkin's lymphoma of the urethra: a rare extranodal entity. Gynecol Oncol 1989;35:110-111.

11 Pak K, Takayam T, Takeoka 0: Reticulum cell sarcoma of the female urethra: report of a case. Acta Urol Jpn 1980;26:599-601.

-12 Simpson RH, Bridger JE, Anthony PP, et al: Malignant lymphoma of the lower urinary tract. A clinicopathological study with review of the literature. Br J Urol 1990;65:254-260.

13 Touhami H, Brahimi S, Kubisz P, Cronberg S: NonHodgkin's lymphoma of the female urethra. J Urol 1987;137:991-992.

14 Selch MT, Mark RJ, Fu YS, et al: Primary lymphoma of female urethra: long-term control by radiation therapy. Urology 1993;42:343-346.

15 Vapnek JM, Turzan CW: Primary malignant lymphoma of the female urethra: report of a case and review of the literature. J Urol 1992;147:701-703.

16 Grabstald H, Hilaris B, Henschke U, Whitmore WF Jr: Cancer of the female urethra. Jama 1966;197:835842.

-17 A predictive model for aggressive non-Hodgkin's lymphoma. The International Non-Hodgkin's Lymphoma Prognostic Factors Project. N Engl J Med 1993;329:987-994.

18 Richter LA, Hegde P, Taylor JA 3rd: Primary non-Hodgkin's B-cell lymphoma of the male urethra presenting as stricture disease. Urology 2007;70:1008.e11-1008.e12.

19 Atalay AC, Karaman MI, Basak T, et al: Non-Hodgkin's lymphoma of the female urethra presenting as a caruncle. Int Urol Nephrol 1998;30:609-610.

20 Kakizaki H, Nakada T, Sugano 0, et al: Malignant lymphoma in the female urethra. Int J Urol 1994;1:281282.

-21 Ohsawa M, Mishima K, Suzuki A, et al: Malignant lymphoma of the urethra: report of a case with detection of Epstein-Barr virus genome in the tumour cells. Histopathology 1994;24:525-529.

-22 Kurtman C, Andrieu MN, Baltaci S, et al: Conformal radiotherapy in primary non-Hodgkin's lymphoma of the male urethra. Int Urol Nephrol 2001;33:537-539.

-23 Inuzuka S, Koga S, Imanishi D, et al: Primary malignant lymphoma of the female urethra. Anticancer Res 2003;23:2925-2927.

-24 Ryu JA, Kim B: MR imaging of primary urethral lymphoma in a man. AJR Am J Roentgenol 2003;181:600601.

25 Chuang SS, Chiu AW, Liu H, et al: Primary urethral MALT lymphoma with high proliferation fraction. Histopathology 2005;46:714-715.

-26 Shimizu Y, Ogawa 0, Terachi T, et al: A case of primary urethral lymphoma presenting as a huge mass surrounding the female urethra. Hinyokika Kiyo 1997;43:229-232.

27 Watson EM, Sauer HR, Sadugor MG: Manifestations of the lymphoblastomas in the genito-urinary tract. J Urol 1949;61:626-645.

-28 Allen R, Nelson RP: Primary urethral malignancy: review of 22 cases. South Med J 1978;71:547-550.

-29 Chaitin BA, Manning JT, Ordonez NG: Hematologic neoplasms with initial manifestations in lower urinary tract. Urology 1984;23:35-42.

30 Rajan N, Allman D, Scaglia B, et al: NonHodgkin's lymphoma of the male urethra. J Urol 1995;153:19161917.

31 Dell'Atti C, Missere M, Restaino G, et al: Primary lymphoma of the female urethra. Rays 2005;30:269272.

32 Muraoka K, Hunahashi M, Nagashima M, et al: [A patient with a primary malignant lymphoma surrounding the female urethra]. Hinyokika Kiyo 2009;55:357-360. 